\title{
Türkiye'de Bireysel Emeklilik Sistemi: Modelleme ile Gelişiminin Değerlendirilmesi (Individual Pension System in Turkey: Modeling and Evaluation of Development)
}

\author{
Özgül YALÇIN ${ }^{\text {iD }}$ Beyhan MARŞAP ${ }^{\text {D b }}$ \\ a Gaziantep Üniversitesi, Nizip Meslek Yüksekokulu, Gaziantep, Türkiye. ozyalcin@gantep.edu.tr \\ b Ankara Hacı Bayram Veli Üniversitesi, İktisadi ve İdari Bilimler Fakültesi, Ankara, Türkiye. beyhan.marsap@hbv.edu.tr
}

MAKALE BILGISI ÖZ ÖZT

\section{Anahtar Kelimeler: \\ Bireysel Emeklilik Sistemi \\ Devlet Katkısı \\ Otomatik Katılım Sistemi \\ Gelişim Modeli}

Gönderme Tarihi 12 Mart 2019

Revizyon Tarihi 22 Nisan 2019

Kabul Tarihi 25 Mayıs 2019

Makale Kategorisi:

Araştırma Makalesi
Amaç - Türkiye'de uygulanmakta olan Bireysel Emeklilik Sisteminin genel hatlarıyla incelendiği bu çalışma, katılımcı sayısındaki değişimin ve buna bağlı olarak Bireysel Emeklilik Sisteminin gelişiminin ortaya konulması amacıyla yapılmıştır. Bu çalışmada katılımcı sayısındaki değişim temelde üç dönem halinde ele alınmıştır. Bu dönemlere ilişkin olarak Bireysel Emeklilik Sisteminin gelişimi hususunda değerlendirmeler yapılmıştır.

Yöntem - Bu çalışmada Bireysel Emeklilik Sisteminin gelişim modeli tahmin edilmeye çalışılmıştır. Bu doğrultuda istatistiksel analiz yöntemleri kullanılarak yapılan çözümlemede Emeklilik Gözetim Merkezi tarafından halka açık olarak paylaşılan verilerden katılımcı sayısı verileri kullanılmıştır.

Bulgular - Çalışmada ele alınan dönemler için yapılan regresyon çözümlemesi neticesinde, ilk iki dönemde daha fazla olmak üzere genel olarak katılımcı sayısının pozitif yönlü bir gelişme gösterdiği tespit edilmiştir. Ancak üçüncü dönemin son aylarına doğru bir önceki zaman periyoduna göre katılımcı sayısının negatif yönlü bir performans sergilediği görülmüştür.

Tartışma - Yapılan çözümlemeler neticesinde elde edilen bulgulardan hareketle katılımcı sayısının genel olarak pozitif yönlü bir gelişim göstermesi ve buna bağlı olarak Bireysel Emeklilik Sisteminin gelişimi, alanyazında yapılan diğer araştırmaların sonuçları ile kısmen benzerlik göstermektedir.

\begin{tabular}{l}
\hline ARTICLE INFO \\
Keywords: \\
Individual Pension System \\
State Contribution \\
Automatic Participation \\
System \\
Development Model
\end{tabular}

Received 12 March 2019

Revised 22 April 2019

Accepted 25 May 2019

Article Classification:

Research Article

\section{ABSTRACT}

Purpose - This study, which examined the general lines of the private pension system is being implemented in Turkey, the change in the number of participants and was conducted in order to reveal the development of the private pension system accordingly. The change in the number of participants has been examined as three periods. Regarding these periods, evaluations were made about the development of the Private Pension System.

Design/methodology/approach - In this study, the development model of the Private Pension System is tried to be estimated. In this analysis, the number of participants from the data shared publicly by the Pension Monitoring Center was used.

Findings - As a result of the regression analysis conducted for the periods covered in the study, it was determined that the number of participants, in general, showed a positive development in the first two periods. However, according to the previous period, the number of participants showed a negative performance towards the last months of the third period.

Discussion - The positive number of participants in general and the development of the Individual Pension System are partly similar to the results of other studies in the literature. 


\section{Giriş}

İhtiyaçların sınırsız oluşu her bireyde farklı şekillenebilmektedir. Bireyler zorunlu ihtiyaçlar ile lüks ihtiyaçlar arasında ihtiyaç planlaması yaparken çok farklı değişkenlerin etkisi altında kalmaktadırlar.. Özellikle geleceğe yönelik planlamalarda bu durum daha farklı bir görünüme bürünmektedir. Geleceğe yönelik planlama yapan bireyler aynı zamanda geleceğe yönelik birikim yapma yoluna gitmektedir. Bu durumda bireylerin gelecek dönemlere yatırım yapma ihtiyacı da ön plana çıkmaktadır. Bu doğrultuda tercih edilen çeşitli yatırım araçlarının var olmasının yanı sıra bireysel emeklilik sistemi de bir çeşit yatırım aracı olarak görülmektedir.

Dünya genelinde yaşanan çeşitli sosyo-ekonomik olaylar ülkeleri sosyal güvenlik alanında yeni arayışlara yöneltmiştir. Bu doğrultuda alternatif bir sistem olarak görülen bireysel emeklilik sisteminin ilk örneği 1980'li yıllarda Şili'de görülmektedir (Şener ve Akın, 2010). Şili'den sonra yeniden yapılanmaya giden ülkelerden Peru 1993 yılında, Arjantin ve Kolombiya 1994 yılında, Meksika 1997 yılında ve Macaristan ise 1998 yılında çeşitli reformlar gerçekleştirmiştir (Gürbüz ve Ekinci, 2003).

Türkiye'de sosyal güvenlik sistemi çerçevesinde çıarılan çeşitli prim afları, erken emekli olunması ve bu bağlamda çalışma potansiyeli olan bireylerin devletten emekli maaşı alması, sosyal güvenlik sistemi bünyesinde toplanan primlerin etkin kullanılmaması gibi faktörler sosyal güvenlik kurumunun etkinliğini olumsuz yönde etkilemiştir. Bu doğrultuda sosyal güvenlik alanında reforma ihtiyaç duyulması bireysel emeklilik sistemini ön plana çıkarmı̧̧ırı (Can, 2010). Dünya genelindeki gelişmelerin yanı sıra ülkemizde de 1990'lı yılların sonlarına doğru sosyal güvenlik sisteminde reform çalışmalarına başlanmıştır.

Alanyazındaki araştırmalardan Can (2010) Türkiye'de Bireysel Emekliliğin Durumu ve Gelişimini ele aldığı çalışmasında sistemin kısa bir geçmişinin olmasına rağmen önemli bir başarı gösterdiğine vurgu yapmıştır. Bununla birlikte BES kapsamındaki fon büyüklügünün 9.997,2 milyon TL ve katılımcı sayılarının da 2.110.385 kişiye ulaştı̆̆ını ortaya koymuştur. Apak ve Taşcıyan (2010) BES'in hızlı bir gelişim içerisinde olduğu, 2009 yılı itibariyle katılımcı sayılarının 1.988.322 kişiye ulaştığı ve 9.000.212.294 TL'ye ulaştığını tespit etmiştir. Bunun yanı sıra BES kapsamındaki katılımcıların 25-45 yaş aralığında yoğunlaştığı araştırma sonucunda ortaya konulmuştur. Ayrıca BES'teki sertifika ve sözleşme sayısının her yıl arttığı, BES'deki birikimlerin iyi değerlendirildiği ve bu birikimlerin yatırıma yönlendirilmesiyle emeklilik yatırım fonu getirilerinin pozitif yönde olduğu da araştırma sonuçları arasında yer almaktadır.

Araştırma probleminin belirlenmesi ve çözümüne ilişkin yapılan alanyazın taramasında Bireysel Emeklilik Sistemi (BES)'nin gelişimine yönelik az sayıda çalışmaya rastlanmıştır. Son zamanlarda BES mevzuatında yapılan çeşitli düzenlemeler de göz önüne alınarak BES'in mevcut durumu ve gelişimine yönelik olarak planlanan bu çalışma, yapılacak olan araştırmalara da yön vereceği hususunda ihtiyaç olarak görülmüştür. Bu bağlamda BES'in gelişimin farklı boyutuyla ele alındığı bu makalenin amacı, bireysel emeklilik sisteminin dünya genelindeki gelişiminin incelenmesinin yanı sıra Türkiye'deki tarihsel sürecinin incelenmesi, gelişim modelinin ortaya konulması ve sistemin günümüze kadar olan gelişim süreci hakkında durum analizi yapılması olarak belirlenmiştir. Araştırmanın amacına yönelik olarak BES'te yapılan reformlar çerçevesinde kullanılan katılımcı sayısı verileri üç dönem halinde çözümlenmiş olup her dönemin gelişim modeli ayrı olarak tahmin edilmeye çalışılmıştır.

\section{Türkiye'de Bireysel Emeklilik Sistemi}

Türkiye'de 1999 yılında oluşturulan "Bireysel Emeklilik Komisyonu” tarafından gönüllülük esasına dayanan Bireysel Emeklilik Sistemine yönelik alt yapı çalışmaları başlatılmıştır. Sistemin yasal zemininin oluşturulması ise bu komisyonun hazırladığı "Bireysel Emeklilik Yatırım ve Tasarruf Sistemi Kanun Tasarısının" TBMM tarafından kabulünden sonra 07 Ekim 2001 tarihinde "4632 Sayılı Bireysel Emeklilik Tasarruf ve Yatırım Sistemi Kanununun” yürürlüğe girmesiyle gerçekleşmiştir (Gülay ve Diğerleri, 2017). 27 Ekim 2003 tarihi itibariyle ilk emeklilik planın onaylanması ve emeklilik şirketlerinin faaliyete başlaması ile birlikte sistem fiili olarak çalışmaya başlamıştır (Akın, 2016).

BES faaliyete başladığı 2003 yılını 15.245 katılımcı sayısı ile tamamlarken günümüze bakıldığında 6.810 .935 katılımcı sayısıyla önemli bir gelişme kaydetmiştir. Emeklilik Gözetim Merkezi verilerine göre katılımcıların yaş dağılımına bakıldığında bu katılımcıların büyük bir oranının 35-44 yaş aralığında olduğu görülmektedir ve dolayısıyla daha çok 35-44 yaş aralığındaki katılımcıların sistemi tercih ettiği söylenebilir. 25 yaş altı 
katılımcı oranının az olduğu ve bu bağlamda 25 yaş altı bireylerin sisteme katılım tercihinin diğer yaş gruplarına göre daha az olduğu söylenebilir. Aynı zamanda katılımcıların diğer yaş gruplarına göre dağılımı ise Şekil 1'de verilmiştir.

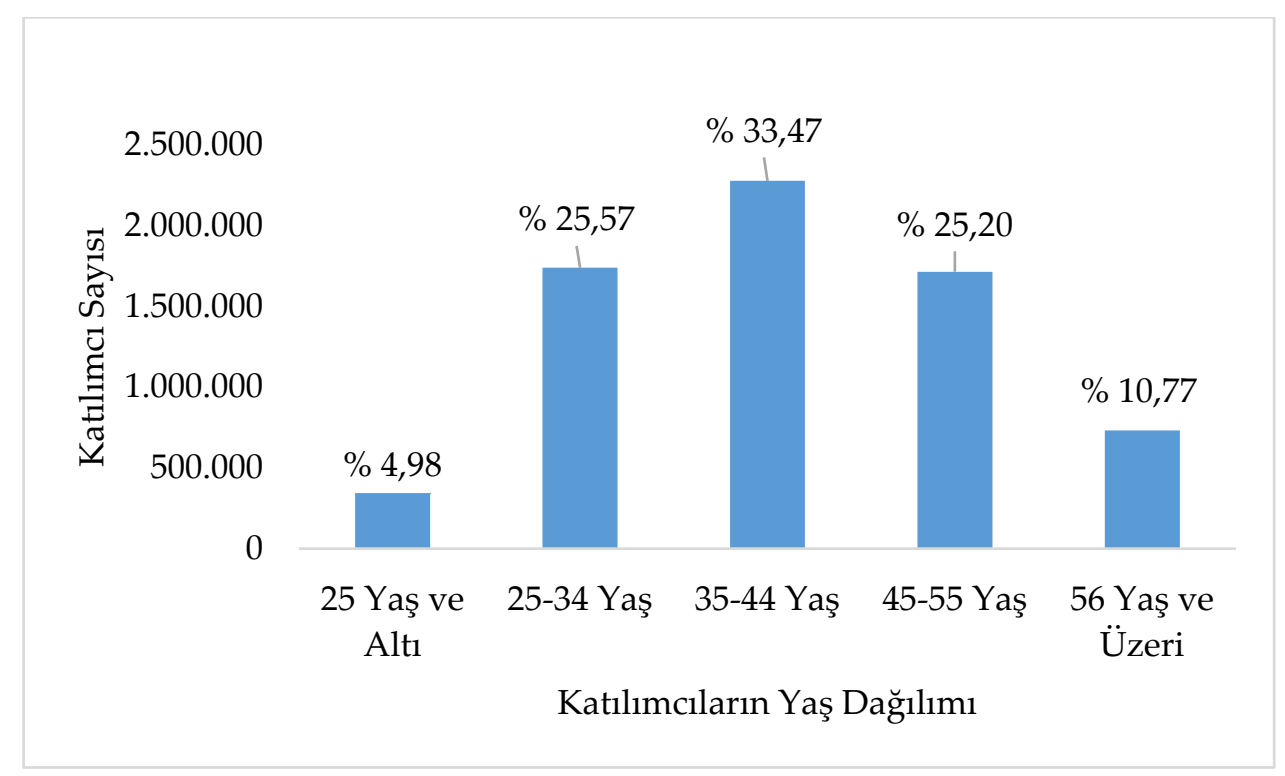

Şekil 1. Bireysel Emeklilik Sistemindeki Katılımcıların Yaş Dağılımı Kaynak: EGM, 2019.

33-45 yaş aralığında olan 2.279.778 katılımcının, BES içerisinde \%33,47 oranla en büyük paya sahip olduğu görülmektedir. $\mathrm{Bu}$ doğrultuda 35-44 yaş aralığındaki bireylerin sisteme katılma eğilimin diğer yaş gruplarına göre daha fazla olduğu görülmektedir. Aynı zamanda 339.347 katılımcı ise \% 4,98 oran ile BES içerisinde en az paya sahiptir ve 25 altı bireylerin BES'e katılım oranının düşük olduğu görülmektedir.

Türkiye'de faaliyet gösteren emeklilik şirketleri aracılığıyla sisteme dâhil olan katılımcılardan sektör toplamında 97.185 katılımcı emekli olmuştur. Bunun yanı sıra bu emeklilik şirketleri bünyesindeki mevcut katılımcı sayısına bakıldığında ise şirket bazında 5 Nisan 2019 tarihi itibariyle 1.121.940 katılımcı ile Garanti Emeklilik ve Hayat AŞ'nin en fazla katılımcısı olan emeklilik şirketi olduğu görülmektedir. Aynı zamanda 34.776 katılımcı ile AXA Hayat ve Emeklilik AŞ’nin sonlarda olduğu görülmektedir (EGM, 2019).

\subsection{Bireysel Emeklilik Sisteminin Tanımı ve Amacı}

Bireysel Emeklilik Sistemi, bireylerin emeklilik dönemlerindeki refah seviyelerini arttırması amacının yanı sıra kamu sosyal güvenlik sisteminin yükünü azaltması, ekonomiye katkı sağlaması ve istihdamı arttırması amaçlarını barındıran bir sistemdir (İnneci, 2013). Başka bir ifadeyle 4632 sayılı Kanunun birinci maddesine göre kamu sosyal güvenlik sisteminin tamamlayıcı bir parçası olarak bireylerin emeklilik dönemlerine ilişkin birikimlerinin yatırıma yönlendirilmesini sağlayarak bireylere emeklilik sürecinde ek bir gelir imkânı sunan bununla birlikte emeklilik sürecinde bireylerin refah seviyesini arttırmayı amaçlayan, uzun vadede ekonomiye kaynak yaratarak istihdam artışını amaçlayan, olumlu ekonomik etkileri ile birlikte gönüllülük esası ve önceden belirlenmiş katkı esasına dayandırılan bir sistem olarak ifade edilebilir. Aynı Kanun kapsamında bireysel emeklilik sistemin genel amaçları ise;

- Kamu sosyal güvenlik sisteminin tamamlayıcı unsuru olması,

- Bireylerin emeklilik sürecindeki refah seviyelerini yükseltmeyi amaçlaması,

- Uzun vadede ekonomiye kaynak yaratması,

- İstihdam artışı sağlaması,

- Ekonomik kalkınma açısından olumlu etkiler yaratması,

olarak sıralanabilir.

\subsection{Devlet Katkisı}

BES'e katılımı arttırmak ve BES'in gelişimine katkı sağlamak amacıyla 6327 sayılı Kanun ile 1 Ocak 2013 tarihinde devlet katkısı uygulamasına geçilmiştir. Devlet katkısı uygulaması katılımcıların ödedikleri katkı payına ek olarak katılımcılar adına devlet tarafından ödenen tutarı ifade etmektedir (İnneci, 2013). Devlet 
katkısı, katılımcılar adına açılmış hesaplarda katılımcıların katkıları oranında ayrı ayrı takip edilmektedir (Kara ve Yildız, 2016).

Devlet katkısı oranının \% 25 olarak belirlenmesinin yanı sıra devlet katkısı miktarına yönelik olarak da bir sınırlama bulunmaktadır. Bir katılımcının alabileceği azami devlet katkısı tutarı brüt asgari ücret üzerinden tespit edilmekte olup bu tutar yıllık asgari ücretin \% 25'i ile sınırlandırılmıştır (EGM, 2019). Ayrıca devlet katkısının hak edilmesine yönelik olarak bir takım düzenlemeler yapılmıştır. Bu düzenlemeler doğrultusunda devlet tarafından ödenen katkıya yönelik olarak katılımcı sistemde geçirilen süreye göre devlet katkısının bir kısmına veya tamamına hak kazanmaktadır. Bu doğrultuda katılımcıların devlet katkısı hesabındaki tutarlarına ilişkin hak kazanma oranları sistemde en az 3 yıl kalan katılımcılar için \% 15, sistemde en az 6 yıl kalan katılımcılar için \% 35, sitemde en az 10 kalan katılımcılar için \% 60, emeklilik, vefat ve maluliyet durumlarında ise devlet katkısı tutarının tamamı olarak belirlenmiştir (Kara ve Yıldız, 2016).

\subsection{Otomatik Katılım Sistemi}

Türkiye'de tasarruf düzeyinin düşük olması, tasarrufları arttırmaya yönelik politikaların oluşturulmasında önemli bir etken olmuştur. Bu doğrultuda bireysel emeklilik sistemi önemli bir tasarruf aracı olarak görülerek tasarrufların artırılması konusunda bireylerin BES'e otomatik katılımını kapsayan bir düzenlemeye ihtiyaç duyulmuştur. Ülkede tasarrufların artmasını amaçlayan bu düzenleme 45 yaş altı olan çalışan bireyleri kapsamaktadır (Akın, 2016). Genel bir ifadeyle otomatik katılım sistemi 45 yaş altı kamu ve özel sektör çalışanlarının BES'e otomatik olarak katılımını sağlayan ve katılımcıların diledikleri zaman sistemden çıkışına imkân tanıyan bir uygulama olarak açıklanabilir (Peker, 2016).

Otomatik katılım sistemi 6740 sayılı Kanun ve 2017/9721 karar numaralı yönetmelik ile düzenmiş olup 1 Ocak 2017 tarihinden itibaren bireylerin BES'e katılımı kademeli olarak gerçekleştirilmektedir. İlgili Kanun ve yönetmelik kapsamında bireylerin sisteme otomatik olarak katılımı hususunda, aktif çalışma ve yaş kriteri dışında sisteme geçiş sürecine yönelik de düzenlemeler yapılmıştır. Bu düzenlemelere göre kamu ve özel sektör çalışanları sisteme kademeli olarak dahil edilmektedir. Bu bağlamda kamu çalışanlarının sisteme dahil sürecinde belirlenen geçiş tarihleri;

- 5018 sayılı Kamu Mali Yönetimi ve Kontrol Kanunu'nun eki (I), (II), (III) ve (IV) sayılı cetvellerde yer alan kamu idarelerinde çalışanlar için 1 Nisan 2017,

- Yerel Yönetimler, KİT’ler, BİT’ler ve Diğer Kamu Kurum ve Kuruluşlarında çalışanlar için 1 Ocak 2018,

olarak belirlenmiştir. Özel sektör çalışanlarının kapsama alınma tarihleri ise;

- 1.000 ve daha fazla çalışanı olan işverene bağlı çalışanları için 1 Ocak 2017,

- 250-999 arası çalışanı olan işverene bağlı çalışanları için 1 Nisan 2017,

- 100-249 arası çalışanı olan işverene bağlı çalışanları için 1 Temmuz 2017,

- 50-99 arası çalışanı olan işverene bağlı çalışanları için 1 Ocak 2018,

- 10-49 arası çalışanı olan işverene bağlı çalışanları için 1 Temmuz 2018,

- 5-9 arası çalışanı olan işverene bağlı çalışanları için 1 Ocak 2019,

olarak belirlenmiştir. Ayrıca otomatik olarak BES'e dahil edilen çalışanlara ilk iki ay içerisinde herhangi bir kesinti yapılmaksızın cayma hakkı da verilmiştir. Bu bağlamda BES'ten çıkmak isteyen katılımcılar cayma haklarını kullanarak BES'ten çıkış yapabilmektedir.

\section{Araştırma Yöntemi}

\subsection{Araştırmanın Amacı ve Araştırma Modeli}

Ülkemizde uygulanmakta olan BES'in genel hatlarıyla incelendiği bu araştırmanın esas amacı Türkiye'de BES kapsamında katılımcı sayılarındaki gelişimi incelemektir. Bu amaç doğrultusunda bu çalışma devlet katkısı uygulaması öncesi, devlet katkısı uygulaması sonrası ve otomatik katılım sistemi sonrası katılımcı sayılarının durumuna yönelik üç dönem halinde ele alınmıştır ve araştırma modeli dönemlere ilişkin olarak katılımcı sayılarındaki artış eğilimini tahmin etmeye yönelik olarak tasarlanmıştır. Bu bağlamda araştırmanın alt problemleri ise şu şekildedir;

1. Bireysel emeklilik sisteminde birinci döneme ilişkin katılımcı sayısındaki değişim nedir? 
2. Bireysel emeklilik sisteminde ikinci döneme ilişkin katılımcı sayısındaki değişim nedir?

3. Bireysel emeklilik sisteminde üçüncü döneme ilişkin katılımcı sayısındaki değişim nedir?

\subsection{Verilerin Toplanması ve Analizi}

Bu çalışmada katılımcı sayısı verileri kullanılmıştır. Veriler Emeklilik Gözetim Merkezi (EGM)'nin resmi internet sitesinden 15.04.2019 tarihinde alınmış olup verilerin tarihsel değişimi incelenmiştir. Bu doğrultuda inceleme üç dönem halinde gerçekleştirilmiştir. Birinci dönem BES kapsamındaki katılımcı sayısının yıl bazındaki değerlerinden oluşmaktadır ve devlet katkısı uygulaması öncesini yani 2003-2012 dönemini kapsamaktadır. İkinci Dönem, devlet katkısı uygulaması ile otomatik katılım sistemi uygulaması arasındaki süreci yani 2013-2016 dönemini kapsamaktadır ve bu döneme ilişkin yapılan regresyon çözümlemesinde altı aylık katılımcı sayısı verileri kullanılmıştır. Üçüncü dönem ise otomatik katılım sistemi uygulaması sonrasını yani 2017-2018 dönemini kapsamaktadır ve bu döneme ilişkin yapılan regresyon çözümlemesinde katılımcı sayısının aylık verileri kullanılmıştır. Ayrıca araştırmada kullanılan verilere otomatik katılım sertifikası verileri dâhil edilmemiştir. Araştırmada kullanılan veriler analiz öncesi yeniden tasarlanarak IBM SPSS (Statistical Package for the Social Sciences) istatistik analiz programı kullanılarak doğrusal regresyon analizi ile çözümlenmiştir.

Doğrusal regresyon, sayısal bağımlı bir değişken ile bağımsız değişken arasındaki ilişkiyi modelleyen yaklaşım olarak ifade edilmektedir. Basit doğrusal regresyon ise modeldeki bağımsız değişken sayısıyla açıklanmaktır. Yani modeldeki bağımsız değişken sayısı bir ise bu model basit doğrusal regresyon olarak ifade edilmektedir (Kılıç, 2013). Basit doğrusal regresyon denklemi genellikle $Y=a+b X$ şeklinde gösterilmektedir. Bu denklemdeki $a$ terimi $X=0$ iken $Y^{\prime}$ nin alacağı ortalamanın tahmini sabit değerini, $b$ terimi ise $X^{\prime}$ de meydana gelen bir birimlik artışı $Y^{\prime}$ de yaratacağı ortalama değişim miktarını gösteren regresyon katsayısını ifade etmektedir (Taşpınar, 2017; 209, 211).

\section{Bulgular}

\subsection{Bireysel Emeklilik Sisteminde 2003-2012 Döneminin Değerlendirilmesi}

Türkiye'de faaliyet gösteren emeklilik şirketleri aracılığıyla sisteme dâhil olan katılımcı sayılarının sektör toplamına yönelik olarak yıllar itibariyle değişimi incelendiğinde BES'in ikinci yılında katılımcı sayısının bir önceki yıla göre yaklaşık olarak 19.61 kat artış gösterdiği görülmektedir. Ancak sonraki. yıllarda oransal olarak bu etkinlik görülememiştir Ayrıca katılımcı sayısı 2003 yılı sonunda 15.245 iken bu sayı 2012 yılı sonunda 3.128.130 olmuştur. Katılımcı sayısının 2003-2012 dönemine ilişkin olarak yıllar itibariyle mevcut durumu ve bir önceki yıla göre yaklaşık artış oranı Tablo 1'de gösterilmiştir.

Tablo 1. 2003-2012 Dönemi Katılımcı Sayısı

\begin{tabular}{|c|c|c|}
\hline \multirow{2}{*}{ Tarih } & \multicolumn{2}{|c|}{ Katılımcı Sayısı } \\
\hline & Mevcut Durum & Yıl Bazında Değişim \\
\hline 31.12 .2003 & 15.245 & - \\
\hline 31.12 .2004 & 314.257 & 19,61 \\
\hline 31.12.2005 & 672.696 & 1,14 \\
\hline 31.12 .2006 & 1.073 .650 & 0,60 \\
\hline 31.12 .2007 & 1.457 .704 & 0,36 \\
\hline 31.12 .2008 & 1.745 .354 & 0,20 \\
\hline 31.12 .2009 & 1.987 .940 & 0,14 \\
\hline 31.12 .2010 & 2.281 .478 & 0,15 \\
\hline 31.12.2011 & 2.641 .843 & 0,16 \\
\hline 31.12.2012 & 3.128 .130 & 0,18 \\
\hline
\end{tabular}

Kaynak: EGM,2019 
Türkiye'de BES kapsamında 2003-2012 dönemine ilişkin ele alınan zaman periyodunun bireylerin sisteme katılımı hususunda yani BES'teki katılımcı sayısının yordayıcısı olup olmadığı basit doğrusal regresyon analizi ile çözümlenmiştir. Öncelikle bu testin kullanım koşulları analiz edilmiştir. Buna göre yordanan (bağımlı) değişken olan katılımcı sayısı ile yordayan (bağımsız) değişken olarak kabul edilen zaman periyodu dağılımının normalliği Shapiro-Wilk (S-W) testi ile analiz edilmiş olup her iki değişkenin de normal dağılım gösterdiği belirlenmiştir ve bu duruma ilişkin bulgular şu şekildedir; $S-W_{K S}=0,978 ; p=$ $0,951>0,05 S-W_{Z P}=0,970 ; p=0,892>0,05$ (KS: Katılımc1 Sayıs1; ZP:Zaman Periyodu). Ayrıca iki değişken arasında doğrusal bir ilişkinin olup olmadığı saçılma diyagramı çizilerek kontrol edilmiş olup iki değişken arasında $r=0,998$ oranında pozitif doğrusal bir ilişki olduğu tespit edilmiştir. Bu sonuçlara göre basit doğrusal regresyon analizi uygulama koşullarının sağlandığı belirlenmiş olup yapılan çözümlemeye ilişkin bulgular aşağıdaki tablolarda sunulmuştur.

Tablo 2. Araştırmada Ele Alınan Değişkenlere İlişkin Betimsel İstatistik Sonuçları

\begin{tabular}{|lcc|}
\hline Değişkenler & $\overline{\mathbf{X}}$ & SS \\
\hline Katılımcı Sayısı (Yordanan) & 1,531 & 0,322 \\
Zaman Periyodu (Yordayan) & 4,500 & 0,957 \\
\hline
\end{tabular}

Araştırmada yordayan değişken olarak kabul edilen zaman periyodu ortalaması 4,50; yordanan değişken olarak kabul edilen katılımcı sayısının ortalaması ise 1,53 olarak belirlenmiştir.

Tablo 3. Basit Doğrusal Regresyon Analizi Sonuçları

\begin{tabular}{|l|c|c|c|c|c|c|c|c|c|c|}
\hline $\begin{array}{l}\text { Yordayan } \\
\text { Değişken }\end{array}$ & $\mathbf{R}$ & $\mathbf{R}^{2}$ & $\mathbf{F}$ & $\mathbf{P}$ & $\begin{array}{c}\mathbf{a} \\
\text { (Sabit) }\end{array}$ & $\mathbf{t}$ & $\mathbf{p}$ & $\begin{array}{c}\mathbf{b} \\
\text { (Reg.K.) }\end{array}$ & $\mathbf{t}$ & $\mathbf{p}$ \\
\hline $\begin{array}{l}\text { Zaman } \\
\text { Periyodu }\end{array}$ & 0,998 & 0,996 & $2.003,468$ & 0,000 & 0,021 & 0,534 & 0,000 & 0,336 & 44,760 & 0,000 \\
\hline
\end{tabular}

Yapılan analiz sonucunda yordayan (bağımsız değişken) zaman periyodu ile yordanan (bağımlı değişken) katılımcı sayısı arasında pozitif yönde anlamlı bir ilişki tespit edilmiştir ( $\left.R=0,998 ; R^{2}=0,996\right)$. BES'in geçirdiği yıllık zaman periyotlarının katılımcı sayısının anlamlı bir yordayıcısı olduğu tespit edilmiştir ( $\mathrm{F}_{(1-}$ 8) $=2.003,468 ; \mathrm{p}<0,05$ ). Bu doğrultuda katılımcı sayısındaki değişimin (toplam varyansın) \% 99,6'sı yıllık zaman periyodu ile açılanabilir $\left(R^{2}=0,996\right)$. Katılımcı sayısının 2003-2012 dönemine yönelik yapılan analiz sonucunda regresyon denklemi; $Y_{K S \text { 2003-2012 }}=0,021+0,336 X_{Y l l}$ biçiminde elde edilmiş olup tahmin denklemine ilişkin model aşağıda sunulmuştur.

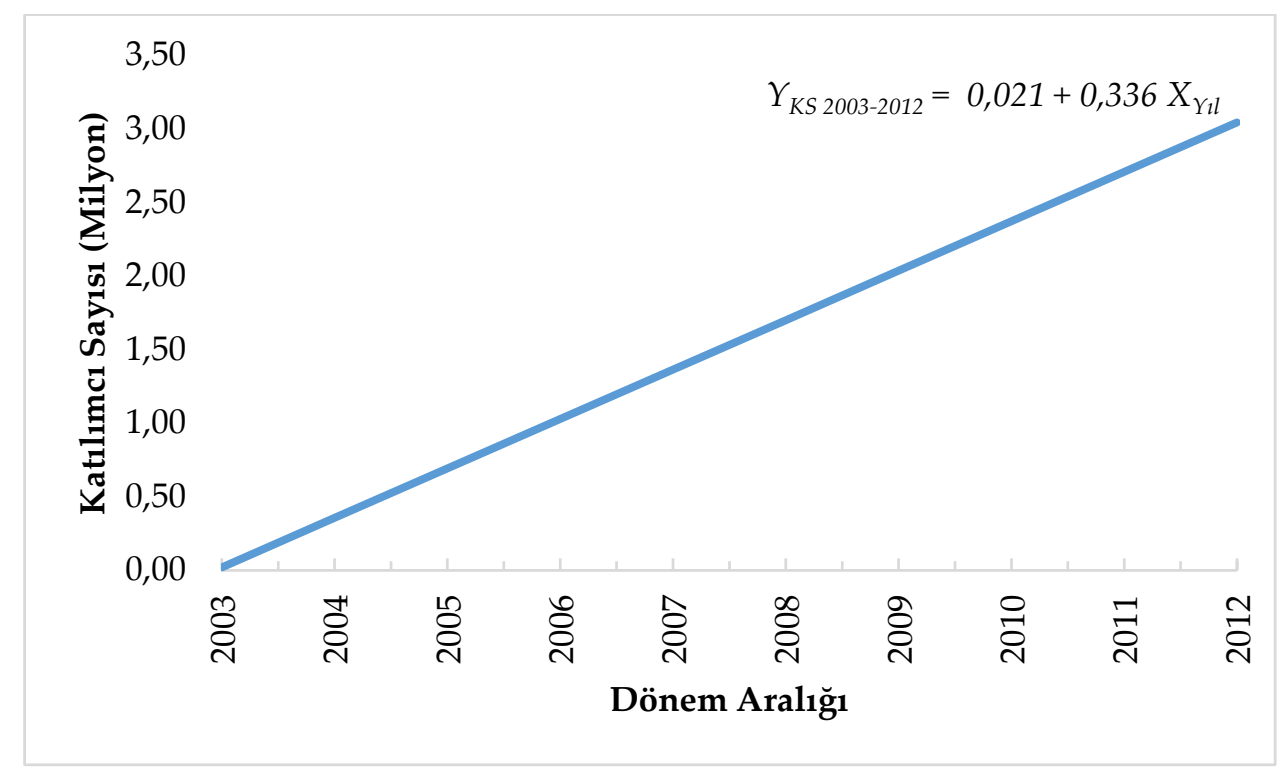

Şekil 2. Katılımcı Sayısı 2003-2012 Dönemi Gelişim Modeli 
Modelde görüldüğü gibi bir yıllık zaman sürecine bağlı olarak katılımcı sayısında yaklaşık 0,336 oranında artış meydana geldiği veya bir yıllık zaman sürecinin sonunda katılımcı sayısının artış katsayının yaklaşık 0,336 olarak tahmin edildiği söylenebilir. $t$ değerlerinin anlamlılık düzeyleri $(p=0,000)$ hem sabit terimi hem de regresyon katsayısını anlamlı bir şekilde yordamaktadır.

\subsection{Bireysel Emeklilik Sisteminde 2013-2016 Döneminin Değerlendirilmesi}

Türkiye'de 1 Ocak 2013 tarihi itibariyle devlet katkısı uygulamasına geçildiği yukarıda belirtilmişti. Bu doğrultuda \% 25 oranında Devlet tarafından katılımcılar adına yapılan katkının sistemi daha cazip hale getirdiği ve bireylerin sisteme girme eğilimini arttıracağı düşünülebilir. Dolayısıyla bir önceki yıla göre 2012 yılında yaklaşık 0,18 oranındaki katılımcı sayısı artışının 2013 yılı sonunda yaklaşık 0,33 oranında olması bu durumu destekler niteliktedir. EGM verilerine göre 2013 yılının ilk yarısında 3.688.127'ye ulaşan katılımcı sayısı 2016 yılı sonu itibariyle 6.373.401'e ulaşmıştır. Ayrıca 2003-2012 dönemine ilişkin katılımcı sayısı, katılımcı sayısının bir önceki döneme göre altı aylık ve yıllık periyotlardaki oransal değişimi Tablo $4^{\prime}$ de sunulmuştur.

Tablo 4. 2013-2016 Dönemi Katılımcı Sayısı

\begin{tabular}{|l|r|r|r|}
\hline \multirow{2}{*}{ Tarih } & \multicolumn{3}{|c|}{ Katılımcı Sayısı } \\
\cline { 2 - 5 } & \multirow{2}{*}{ Mevcut Durum } & \multicolumn{2}{|c|}{ Değişim } \\
\cline { 2 - 5 } & & Altı Aylık & Yıllık \\
\hline 30.06 .2013 & 3.688 .127 & 0,18 & - \\
\hline 31.12 .2013 & 4.153 .055 & 0,13 & 0,33 \\
\hline 30.06 .2014 & 4.645 .565 & 0,12 & 0,23 \\
\hline 31.12 .2014 & 5.092 .871 & 0,10 & - \\
\hline 30.06 .2015 & 5.565 .583 & 0,09 & 0,19 \\
\hline 31.12 .2015 & 6.038 .432 & 0,08 & - \\
\hline 30.06 .2016 & 6.373 .401 & 0,06 & 0,10 \\
\hline 31.12 .2016 & 6.627 .025 & 0,04 & \\
\hline
\end{tabular}

Kaynak: EGM,2019

Katılımcı sayısının 2013-2016 dönemine ilişkin ele alınan zaman periyodunun bireylerin sisteme katılımı konusunda yordayıcı olup olmadığı yani zaman periyodunun BES'teki katılımcı sayısının yordayıcı olup olmadığı basit doğrusal regresyon analizi ile çözümlenmiştir. Öncelikle bu testin kullanım koşulları analiz edilmiştir.

Bu doğrultuda ilk olarak yordanan (bağımlı) değişken olan katılımcı sayısı ile yordayan (bağımsız) değişken olan zaman periyodu dağılımının normalliği Shapiro-Wilk testi ile analiz edilmiş olup her iki değişkenin de normal dağılım gösterdiği belirlenmiştir ve bu analize ilişkin bulgular ise $S-W_{K S}=0,957 ; p=0,782>$ 0,$05 ; S-W_{Z P}=0,975 ; p=0,933>0,05$ (KS:Katılımcı Sayıs1, ZP:Zaman Periyodu) olarak bulunmuştur. Ayrıca iki değişken arasında doğrusal bir ilişki olup olmadığı saçılma diyagramı çizilerek kontrol edilmiş olup iki değişken arasında $r=0,997$ oranında pozitif doğrusal bir ilişki olduğu tespit edilmiştir. Bu sonuçlara göre basit doğrusal regresyon analizi uygulama koşullarının sağlandığı belirlenmiş olup yapılan çözümlemeye ilişkin buldular aşağıdaki tabloda sunulmuştur. 
Ö. Yalçın - B. Marşap 11/2 (2019) 864-875

Tablo 5. Araştırmada Ele Alınan Değişkenlere İliş̧kin Betimsel İstatistik Sonuçları

\begin{tabular}{|lcc|}
\hline Değişkenler & $X$ & SS \\
\hline Katılımcı Sayısı (Yordanan) & 5,273 & 0,376 \\
Zaman Periyodu (Yordayan) & 3,500 & 0,866 \\
\hline
\end{tabular}

Araştırmada yordayan değişken olarak kabul edilen zaman periyodu ortalaması 3,500, yordanan değişken olarak kabul edilen değişken olarak kabul edilen katılımcı sayısının ortalaması 5,273 olarak belirlenmiştir.

Tablo 6. Basit Doğrusal Regresyon Analizi Sonuçları

\begin{tabular}{|c|c|c|c|c|c|c|c|c|c|c|}
\hline $\begin{array}{c}\text { Yordayan } \\
\text { Değişken }\end{array}$ & $\mathbf{R}$ & $\mathbf{R}^{2}$ & $\mathbf{F}$ & $\mathbf{p}$ & $\begin{array}{c}\mathbf{a} \\
\text { (Sabit) }\end{array}$ & $\mathbf{T}$ & $\mathbf{p}$ & $\begin{array}{c}\mathbf{b} \\
\text { (Reg.K.) }\end{array}$ & $\mathbf{t}$ & $\mathbf{p}$ \\
\hline $\begin{array}{c}\text { Zaman } \\
\text { Periyodu }\end{array}$ & 0,997 & 0,993 & 878,382 & 0,000 & 3,760 & 61,599 & 0,000 & 0,432 & 29,638 & 0,000 \\
\hline
\end{tabular}

Yapılan analiz sonucunda yordayan (bağımsız değişken) zaman periyodu ile yordanan (bağımlı değişken) katılımcı sayısı arasında pozitif yönde anlamlı bir ilişki tespit edilmiş edilmiştir $\left(R=0,997 ; R^{2}=0,993\right)$. Bu dönemde BES'in geçirdiği altı aylık zaman periyotlarının katılımcı sayısının anlamlı bir yordayıcısı olduğu tespit edilmiştir $\left(\mathrm{F}_{(1-6)}=878,382 ; \mathrm{p}<0,05\right)$. Bu doğrultuda katılımcı sayısındaki değişimin (toplam varyansın) \% 99,3'ü altı aylık zaman periyodu ile açıklanabilir $\left(R^{2}=0,993\right)$.

Katılımcı sayısının 2013-2016 dönemine yönelik yapılan analiz sonucunda regresyon denklemi;

$$
Y_{K S ~ 2013-2016}=3,760+0,432 X_{\text {Alt } t A y}
$$

biçiminde elde edilmiş olup tahmin denkleme ilişkin model aşağıda sunulmuştur.

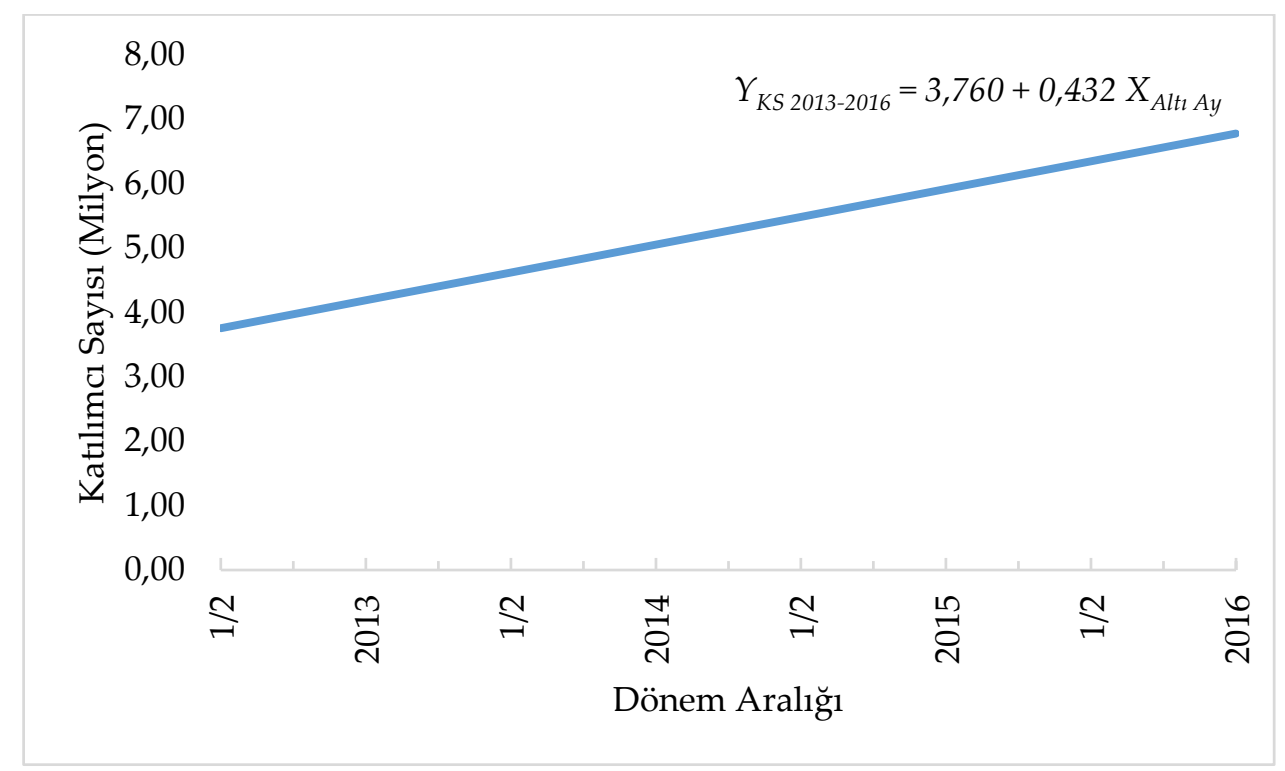

Şekil 3. Katılımcı Sayısı 2013-2016 Dönemi Gelişim Modeli

Modelde görüldüğü gibi altı aylık zaman sürecine bağlı olarak katılımcı sayısında yaklaşık 0,432 oranında artış meydana geldiği veya altı aylık zaman sürecinin sonunda katılımcı sayısının artış katsayının yaklaşık 0,432 olarak tahmin edildiği söylenebilir. $t$ değerlerinin anlamlllık düzeyleri $(\mathrm{p}=0,000)$ hem sabit terimi hem de regresyon katsayısını anlamlı bir şekilde yordamaktadır.

\subsection{Bireysel Emeklilik Sisteminde 2017-2018 Döneminin Değerlendirilmesi}

Ülkemizde 45 yaş altı çalışanların işverenleri aracılığıyla belirlenen bir plan dâhilinde kademeli olarak otomatik BES kapsamına alınması uygulamasının 1 Ocak 2017 tarihi itibariyle yürürlüğe girdiği yukarıda 
belirtilmişti. Bu doğrultuda BES kapsamındaki katılımcı sayısının bu dönemde önemli artış kaydedeceği beklenmektedir. Ancak bu döneme ilişkin verilerin otomatik katılım sertifikası verilerinden arındırılmış olması nedeniyle bu dönemi kapsayan analiz bulgularının OKS kapsamı dışında bireylerin kendi tercihlerine göre sisteme dâhil olduğu yönündedir ve bu bağlamda BES'in son dönemlerinde tercih edilme durumunu da kismen ortaya koymaktadır. Ayrıca BES'in tercih edilme durumu ortaya konulurken BES'e dâhil olmak isteyen bireylerin OKS kapsamında sisteme dâhil olmaları da göz önünde bulundurulduğundan dolayı bu dönemdeki regresyon katsayısının düşük olması beklenmektedir.

Bu döneme ilişkin katılımcı sayısı verileri aşağıdaki tabloda sunulmuştur.

Tablo 7. 2017-2018 Dönemi Katılımcı Sayısı

\begin{tabular}{|c|c|c|c|c|}
\hline \multirow{3}{*}{ Tarih } & \multicolumn{4}{|c|}{ Katılımcı Sayısı } \\
\hline & \multirow{2}{*}{ Mevcut Durum } & \multicolumn{3}{|c|}{ Değişim } \\
\hline & & Aylık & Altı Aylık & Yillik \\
\hline 31.01 .2017 & 6.718 .734 & 0,014 & - & - \\
\hline 28.02 .2017 & 6.743 .201 & 0,004 & - & - \\
\hline 31.03 .2017 & 6.748 .008 & 0,001 & - & - \\
\hline 30.04 .2017 & 6.761 .265 & 0,002 & - & - \\
\hline 31.05 .2017 & 6.791 .227 & 0,004 & & - \\
\hline 30.06 .2017 & 6.811 .854 & 0,003 & 0,028 & - \\
\hline 31.07.2017 & 6.825 .250 & 0,002 & - & - \\
\hline 31.08 .2017 & 6.831 .589 & 0,001 & - & - \\
\hline 30.09.2017 & 6.842 .125 & 0,002 & - & - \\
\hline 31.10 .2017 & 6.867 .789 & 0,004 & - & - \\
\hline 30.11 .2017 & 6.898 .042 & 0,004 & - & - \\
\hline 31.12 .2017 & 6.924 .945 & 0,004 & 0,017 & 0,045 \\
\hline 31.01 .2018 & 6.926 .368 & 0,000 & - & - \\
\hline 28.02.2018 & 6.949 .032 & 0,003 & - & - \\
\hline 31.03 .2018 & 6.955 .794 & 0,001 & - & - \\
\hline 30.04 .2018 & 6.965 .986 & 0,001 & - & - \\
\hline 31.05 .2018 & 6.977 .179 & 0,002 & - & - \\
\hline 30.06 .2018 & 6.984 .044 & 0,001 & 0,009 & - \\
\hline 31.07.2018 & 6.975 .087 & $-0,001$ & - & - \\
\hline 31.08 .2018 & 6.974 .925 & 0,000 & - & - \\
\hline 30.09 .2018 & 6.946 .230 & $-0,004$ & - & - \\
\hline 31.10 .2018 & 6.902 .906 & $-0,006$ & - & - \\
\hline 30.11 .2018 & 6.883 .738 & $-0,003$ & - & - \\
\hline 28.12 .2018 & 6.875 .886 & $-0,001$ & $-0,015$ & $-0,007$ \\
\hline
\end{tabular}

Katılımcı sayısının 2017-2018 dönemine ilişkin verileri incelendiğinde bu dönemin ilk yılında bir önceki yıla göre yaklaşık olarak 0,045 oranında artış gösterdiği ancak ikinci yılında yaklaşık -0,007 oranında negatif bir performans sergilediği görülmektedir. Katılımcı sayısının altı aylık oranlarına bakıldığında bir önceki döneme göre bu dönemin ilk altı ayındaki artış oranı yaklaşık 0,028 iken bu dönemin son altı ayında bu oran - 0,015 oranla negatif yönlü olmuştur. Aylık bazdaki değişime bakıldığında ise son aylarda katılımcı sayısında negatif yönlü bir değişim olduğu görülmektedir.

Katılımcı sayısının 2017-2018 dönemi içerisinde ele alınan zaman periyodunun bireylerin BES'e katılımı konusunda yani BES'teki katılımcı sayısının yordayıcısı olup olmadığı basit doğrusal regresyon analizi ile çözümlenmiştir. Bu testin kullanım koşullarına yönelik olarak yapılan analizde yordanan değişken olan katılımcı sayısı ile yordayan değişken olan zaman periyodu dağılımının normalliği Shapiro-Wilk testi ile analiz edilmiştir. Yapılan analiz neticesinde her iki değişkenin de normal dağılım sergilediği belirlenmiştir ve bu analize ilişkin bulgular $S-W_{K S}=0,919 ; p=0,056>0,05 ; S-W_{Z P}=0,959 ; p=0,416>0,05$ biçiminde elde edilmiştir. Ayrıca iki değişken arasında doğrusal bir ilişkinin olup olmadığı saçılma diyagramı çizilerek kontrol edilmiş olup iki değişken arasında $r=0,807$ oranında pozitif doğrusal bir ilişki 
olduğu tespit edilmiştir. Bu sonuçlara göre basit doğrusal regresyon analizi uygulama koşullarının sağlandığı belirlenmiş olup yapılan çözümlemeye ilişkin bulgular aşağıdaki tablolarda sunulmuştur.

Tablo 8. Araştırmada Ele Alınan Değişkenlere İlişkin Betimsel İstatistik Sonuçları

\begin{tabular}{|lcc|}
\hline Değişkenler & $\overline{\mathbf{X}}$ & SS \\
\hline Katılımcı Sayısı (Yordanan) & 6,879 & 0,017 \\
Zaman Periyodu (Yordayan) & 11,500 & 1,443 \\
\hline
\end{tabular}

Araştırmada yordayan değişken olarak kabul edilen zaman periyodu ortalaması 11,500, yordanan değişken olarak kabul edilen değişken olarak kabul edilen katılımcı sayısının ortalaması 6,879 olarak belirlenmiştir.

Tablo 9. Basit Doğrusal Regresyon Analizi Sonuçları

\begin{tabular}{|c|c|c|c|c|c|c|c|c|c|c|}
\hline $\begin{array}{c}\text { Yordayan } \\
\text { Değişken }\end{array}$ & $\mathbf{R}$ & $\mathbf{R}^{2}$ & $\mathbf{F}$ & $\mathbf{p}$ & $\begin{array}{c}\mathbf{a} \\
\text { (Sabit) }\end{array}$ & $\mathbf{t}$ & $\mathbf{p}$ & $\begin{array}{c}\mathbf{b} \\
\text { (Reg.K.) }\end{array}$ & $\mathbf{t}$ & $\mathbf{P}$ \\
\hline $\begin{array}{c}\text { Zaman } \\
\text { Periyodu }\end{array}$ & 0,807 & 0,651 & 41,093 & 0,000 & 6,768 & 335,939 & 0,000 & 0,010 & 6,410 & 0,000 \\
\hline
\end{tabular}

Yapılan analiz sonucunda yordayan zaman periyodu ile yordanan katılımcı sayısı arasında pozitif yönde anlamlı bir ilişki tespit edilmiş edilmiştir ( $R=0,807 ; R^{2}=0,651$ ). $B E S^{\prime}$ in geçirdiği aylık zaman periyotları katılımcı sayısının anlamlı bir yordayıcısı olduğu tespit edilmiştir $\left(\mathrm{F}_{(1-22)}=41,093 ; \mathrm{p}<0,05\right)$. Bu doğrultuda katılımcı sayısındaki değişimin (toplam varyansın) \% 65,1'i aylık zaman periyodu ile açıklanabilir $\left(\mathrm{R}^{2}=\right.$ $0,651)$.

Katılımcı sayısının 2017-2018 dönemine yönelik yapılan analiz sonucunda regresyon denklemi;

$$
Y_{K S ~ 2017-2018}=6,768+0,010 X_{A y}
$$

biçiminde elde edilmiş olup tahmin denklemine ilişkin model aşağıda sunulmuştur.

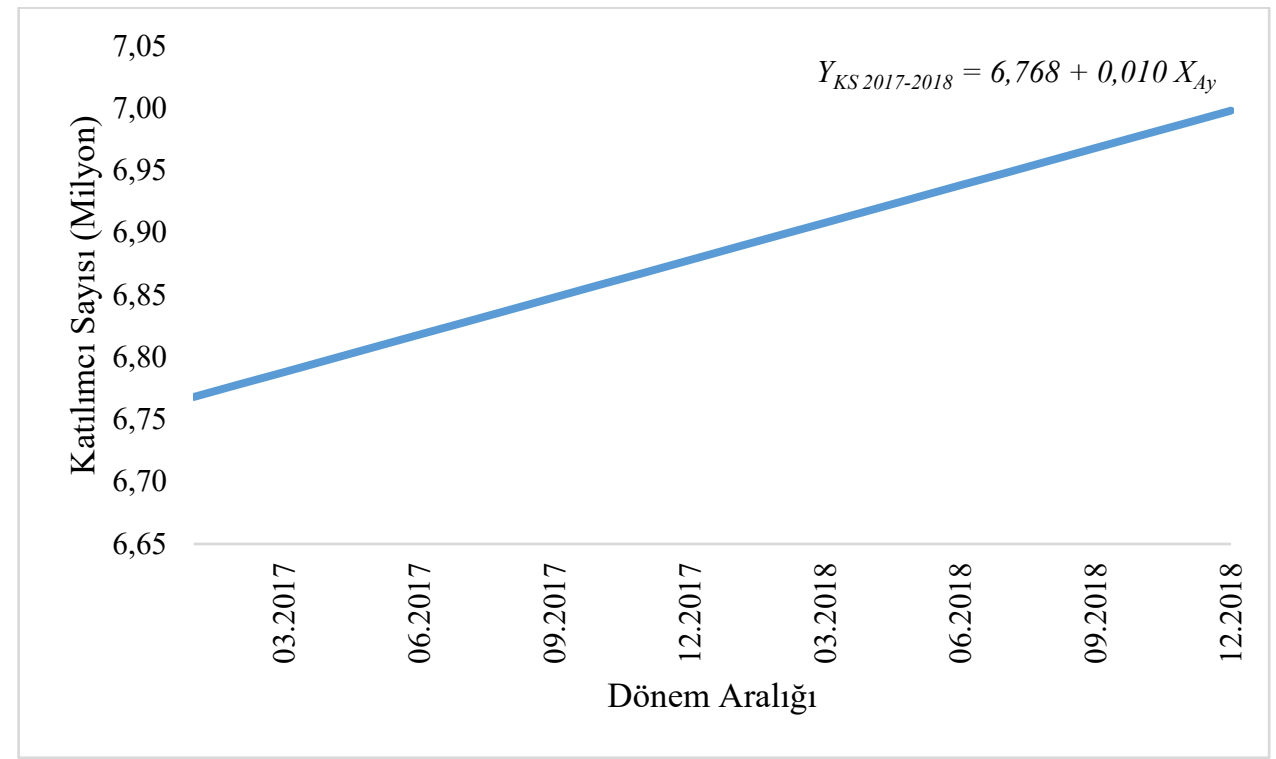

Şekil 4. Katılımcı Sayısı 2017-2018 Dönemi Gelişim Modeli

Modelde görüldüğü gibi 2017-2018 dönemine ilişkin aylık zaman dilimine bağlı olarak katılımcı sayısında yaklaşık 0,010 oranında artış meydana geldiği ya da bu döneme ilişkin bir aylık zaman sürecinde katılımcı sayısının artış katsayısının yaklaşık olarak 0,010 olarak tahmin edildiği söylenebilir. $t$ değerlerinin anlamlılık düzeyleri $(p=0,000)$ hem sabit terimi hem de regresyon katsayısını anlamlı bir şekilde yordamaktadır. 


\section{Sonuç ve Tartışma}

Türkiye'de uygulanmakta olan BES'in genel hatlarıyla incelendiği bu araştırmada BES kapsamındaki katılımcı sayısı basit doğrusal regresyon analizi ile incelenmiştir. Yapılan regresyon çözümlemesinde katılımcı sayısı verileri üç dönem halinde araştırmaya konu olmuştur. BES'in Türkiye'de uygulamaya başlamasından itibaren devlet katkısı uygulamasına kadar olan birinci döneminde, bir önceki yıla göre katılımcı sayısındaki artış oranı 2004 yılında yaklaşık olarak 19,61 iken 2012 yılında bu oran 0,18 olarak ortaya konulmuştur. Birinci döneme ilişkin yapılan regresyon çözümlemesi neticesinde katılımcı sayısı artış katsayısı 0,336 olarak tahmin edilmiştir. Bu bağlamda birinci dönem içerisinde katılımcı sayısının her yıl yaklaşık 0,336 oranında artış gösterdiği söylenebilir. Bunun yanı sıra 2012 yılı sonu itibariyle katılımcı sayısının 3.128.130'a ulaştığı da görülmektedir. Devlet katkısı uygulamasının yürürlüğe girmesinden itibaren otomatik katılım sisteminin yürürlüğe girdiği tarihe kadar olan süreci kapsayan ikinci dönemde, katılımcı sayısının bir önceki yıla göre artış oranı 2013 yılında yaklaşık 0,33 iken bu oran 2016 yılı için 0,10 olarak gerçekleşmiştir. Bunun yanı sıra 2016 yılı itibariyle katılımcı sayısının 6.627.025'a ulaştığı da görülmektedir. Ayrıca ikinci döneme yönelik yapılan regresyon çözümlemesi neticesinde katılımcı sayısı artış katsayısı yaklaşık 0,432 olarak tahmin edilmiştir ve bu dönemde altı aylık zaman süreci içerisinde katılımcı sayısının yaklaşık 0,432 oranında artış gösterdiği ortaya konulmuştur. Otomatik katılım sistemini uygulanmaya başladıktan sonraki süreci kapsayan üçüncü dönemde ise bir önceki yıla göre katılımcı sayısı artış oranı 2017 yılında 0,045 iken 2018 yılında bu oran 0,007 oranla negatif yönlü gerçekleşmiştir. Bunun yanı sıra 2018 yılı itibariyle katılımcı sayısının 6.875 .886 olduğu görülmektedir. Bu döneme ilişkin yapılan regresyon çözümlemesi neticesinde katılımcı sayısı artış katsayısı 0,010 olarak tahmin edilmiştir. Dolayısıyla üçüncü dönemde katılımcı sayısının aylık bazda 0,010 oranında artış gösterdiği söylenebilir. BES'in son dönemindeki katılımcı sayısında diğer dönemlere göre önemli bir artış görülememesi ve özelikle son aylarında katılımcı sayısı artışının negatif yöne dönüşmesi bu dönemde ele alınan verilerin otomatik katılım sertifikası verilerinden arındırılmış olmasına yordanabilir. Kısacası ilk iki dönemde katılımcı sayısında pozitif yönlü gelişmelerin olduğu ve üçüncü dönemde de katılımcı sayısında artış meydana geldiği ancak üçüncü dönemin son aylarında negatif yönlü gerçekleşmelerin olduğu söylenebilir. Bu bağlamda otomatik katılım kapsamındaki verilerden hareketle sistemin gelişimi yönünde çeşitli çalışmaların yapılması önerilmektedir.

\section{Kaynakça}

Bireysel Emeklilik Tasarruf ve Yatırım Sistemi Kanunu İle Bazı Kanun ve Kanun Hükmünde Kararnamelerde Değişiklik Yapılmasına Dair Kanun. (2012, 29 Haziran). Resmi Gazete (Sayı: 28338). Erişim Adresi: http://www.resmigazete.gov.tr/eskiler/2012/06/20120629-1.htm

Bireysel Emeklilik Tasarruf ve Yatırım Sistemi Kanunu. (2001, 7 Nisan). Resmi Gazete (Sayı: 24366). Erişim Adresi: http://www.mevzuat.gov.tr/MevzuatMetin/1.5.4632.pdf

Bireysel Emeklilik Tasarruf ve Yatırım Sistemi Kanununda Değişiklik Yapılmasına Dair Kanun. (2016, 25 Ağustos). Resmi Gazete (Sayi: 29812). Erişim Adresi: http://www.resmigazete.gov.tr/eskiler/2016/08/20160825-4.htm

Çalışanların İşverenleri Aracılığıyla Otomatik Olarak Emeklilik Planına Dâhil Edilmesine İlişkin Usul ve Esaslar Hakkında Yönetmelik. (2017, 2 Ocak). Resmi Gazete (Sayı: 29936). Erişim Adresi: http://www.resmigazete.gov.tr/eskiler/2017/01/20170102-1.pdf

Emeklilik Gözetim Merkezi. (2019, $15 \quad$ Nisan). Erişim Adresi: http://web2.egm.org.tr/webegm2/chart/besgosterge/wg_dataview_tablolu.asp?raportip=1

Emeklilik Gözetim Merkezi. (2019, 15 Nisan). Erişim Adresi: https://www.egm.org.tr/bilgimerkezi/istatistikler/

Emeklilik Gözetim Merkezi. (2019, 2 Nisan). Erişim Adresi: https://www.egm.org.tr/bireyselemeklilik/devlet-katkisi/

Emeklilik Gözetim Merkezi. (2019, 5 Nisan). Erişim Adresi: http://web2.egm.org.tr/webegm2/chart/besgosterge/wg_sirketview_tablolu.asp?raportar1=31.12.2003\& raportar2 $=12.04 .2019 \&$ sirketlist $=100 \&$ raportip $=10 \&$ yayin $=W$ 
Ö. Yalçın - B. Marşap 11/2 (2019) 864-875

Gülay, T , Işık, M , Öztürk, M . (2017). Türkiye'de Bireysel Emeklilik Sistemi ve Akademisyenlerin Otomatik Katılıma Bakış Açılarına İlişkin Bir Analiz: Süleyman Demirel Üniversitesi Örneği. İş ve Hayat Dergisi, 3 (6), 179-205.

İnneci, A. (2013). Bireysel Emeklilik Sisteminde Yapılan Yeni Düzenlemeler ve Değerlendirilmesi, Çukurova Üniversitesi Sosyal Bilimler Enstitüsü Dergisi, 22(1), 105-120.

İnternet: Akın, F . (2016). Otomatik Katılım Sisteminin Bireysel Emeklilik Sektörüne Etkileri. Bilecik Şeyh Edebali Üniversitesi Sosyal Bilimler Enstitüsü Dergisi, 1 (1), 1-12. Web: http://dergipark.gov.tr/bseusbed/issue/27390/288718 adresinden 08.04.2019'da alınmıştır.

İnternet: Apak, S ve Taşcıyan, K. H. "Türkiye'de Bireysel Emeklilik Sisteminin Gelişimi". Ekonomi Bilimleri Dergisi, 2(2010), 121-129 Web: http://dergipark.gov.tr/ebd/issue/4856/66802 adresinden 05.04.2019'da alınmıştır.

İnternet: Can, Y . (2010). Bireysel Emekliliğin Türkiye'deki Durumu Ve Gelişimi. Ekonomi Bilimleri Dergisi, 2 (2), 139-146. Web: http://www.sobiad.org/ejournals/dergi_ebd/arsiv/2010_2/17yesim_can.pdf adresinden 07.04.2019'da alınmıştır.

İnternet: Gürbüz, A. O. ve Ekinci, S. (2003). Bireysel Emeklilik Sistemi ve Sermaye Piyasalarında Beklenen Etkiler. Marmara Üniversitesi Iktisadi ve Ídari Bilimler Dergisi, 18(1), 205-228. Web:http://dosya.marmara.edu.tr/ikf/iib-dergi/2003-1-2/2003_gurbuz-ekinci.pdf adresinden 20.03.2018'de alınmıştır.

İnternet: Kara, S. ve Yıldız, Y. (2016). Türkiye'de Bireysel Emeklilik Sistemi: 2012 Sonrası Yapılan Reformlar ve Beklentiler. İşletme ve Íktisat Çalışmaları Dergisi, 4 (1), 23-45. Web:http://www.isletmeiktisat.com/index.php/iicd/article/view/64/pdf_34 adresinden 10.04.2019'da alınmıştır.

İnternet: Şener, O. ve Akın, F. (2010). Özel Emeklilik Fonları ve Türkiye'de Bireylerin Bireysel Emeklilik Sistemine Giriş Kararlarını Etkileyen Faktörlerin Belirlenmesi Üzerine Bir Araştırma. Marmara Üniversitesi İktisadi ve İdari Bilimler Dergisi, 29 (2), 291-321 Web: http://dosya.marmara.edu.tr/ikf/iib-dergi/2010-2/14-sener-akin.pdf adresinden 11.04.19' da alınmıştır.

Kılıç, S. (2013). Doğrusal Regresyon Analizi. Journal Of Mood Disorders. 3(2), 90-92.

Peker, İ. (2016). Türkiyede Bireysel Emeklilik Sistemindeki Maliyetlerin Düşürülmesi ve Otomatik Katılım Sistemi Üzerine Öneriler. Akdeniz Üniversitesi İktisadi ve İdari Bilimler Fakültesi Dergisi, 16 (33), 34-62.

Taşpınar, M. (2017). Sosyal Bilimlerde SPSS Uygulamalı Nicel Veri Analizi. (I. Baskı). Ankara: Pegem Akademi, 209-211. 